\title{
Assessment of Extrinsic Motivational Variables Influence on Entrepreneurial Performances in a Developing Economy: Perspective of Selected SMEs in Lagos, Nigeria
}

\author{
Akande Olusola \\ Department of Management and Accounting, Faculty of Management Sciences, Ladoke Akintola University of Technology, Ogbomoso, \\ Oyo State, Nigeria
}

\begin{abstract}
It is a known fact that motivation is an important tool for achieving an acceptable level of performance in any establishment. In a growing economy like Nigeria, it is likely that what people want from their jobs differs from individual to individual, depending on the prevailing economic condition and working environment. This study investigates into whether extrinsic motivational variable influences entrepreneurial performances in a developing economy or not. The motivational variables identified for this study comprise of salary increment, job security and regular promotion of employees. This study adopted a descriptive design by administering Four hundred (400) questionnaires to selected entrepreneurs in Lagos state using stratified random sampling technique. Out of the four hundred (400) questionnaires distributed, only three hundred and ten (310) were filled-in and returned. Descriptive statistics (frequencies, tables and percentages) was adopt and T-test Analytical tool was used to test the formulated hypotheses. Finding from Analysis revealed that all the identified extrinsic motivational variables have strong positive influence on entrepreneurial performances, with exception of salary increment. (T-test-cal<T-test -tab $=2.5: T$-test-cal $>T$-test - tab $=4.04: T$-test-cal $>T$-test - tab $=3.9)$ all the identified variables are significant at 0.05 only with exception of salary increment which is not significant at level of 0.05. Based on the result, it was concluded that motivational variables such as job security and regular promotion have significant influence on Entrepreneurial performances in a developing economy.
\end{abstract}

Keywords: Extrinsic Motivational variables; Entrepreneurial performance; Entrepreneur; Growth; SMEs

\section{Introduction}

Developing economies have been characterised by low standard of living, undeveloped industrial base, high rate of unemployment and low Human development Index(HDI) i.e. life expectancy, education and income. With these problems, it is quite empirical that self-development especially in terms of entrepreneurial performances of Small and Medium Enterprises (SMEs), would be a viable and alternative rescue for such nations (GEM 2011). Entrepreneurial performances and operations have been identified across the globe as viable mechanism and means of efficient economic progression, but one of the biggest problems facing management of an establishments in developing nations is how best to get employees committed to their work and put in their best towards the accomplishment of organization's objectives. However studies have shown that there linkage between business turnover and extrinsic motivational variables.

Motivation is a process of inducing, inspiring and energizing people to work willingly with zeal, initiative, confidence, satisfaction and an integrated manner to achieve desired goals. It is a morale boosting activity. Motivation is concerned with why people do what they do. It answers such questions as why do managers or worker go to work and do a good job. This tries to explain what motivates people to act the way they do, with primary focus on the work place. It is the primary task of the Entrepreneur to create and maintain an environment in which employees can work efficiently and realize the objectives of the organization. Every organization and business wants to be successful and have desire to get constant progress. The current era is highly competitive and organizations regardless of size, technology and market focus are facing employee retention challenges. To overcome these restraints, a strong and positive relationship and bonding should be created and maintained between employees and their establishments. Employees of any organization are the most central parts, so they need to be influenced and persuaded towards task fulfilments. For an entrepreneurial to achieve prosperity different strategies need to put in place in order to compete with the competitors and for increasing businessperformance. Employee motivation is one of the policies of an establishment to increase effectual job management amongst employees in organization (Shadier et al. 2009). A motivated employee is responsive to the definite goals and objectives he/she must achieve, therefore he does everything to make sure he follows that direction.

According to Leonard et al (1995) extrinsic motivation is that which derives from external sources. It can be regarded as what management of an organisation do to or for workers to make them exhibit the desired behaviour that will lead to attainment of organisational goals. Extrinsic motivation have no direct relationship with the job itself, rather they are externally mediated and are related to extrinsic motivational variables such as salary, fringe benefits, job security, promotion and other conditions of work. Extrinsic motivations are believed to have an immediate and powerful effect but may not necessarily last long. Extrinsic motivation is that which is derived from the end to which the job provides the means. Evidences from the literature shows that Entrepreneurs are becoming increasingly aware that motivation increases performance because unsatisfied employee produce unsatisfactory result which will 


\section{International Journal of Science and Research (IJSR) \\ ISSN (Online): 2319-7064}

Index Copernicus Value (2015): 78.96 | Impact Factor (2015): 6.391

eventually affect the overall performance of the organisation.

The success of an entrepreneur depends on the ability to provide a motivating environment for its employee. The extent to which extrinsic motivational variables such as salary, job security and promotion can improve entrepreneurial performance is worth exploring. The impact of extrinsic motivation atimproving entrepreneurial performances has not been greatly explored in Nigeria. Most studies in Nigeria focus on the performance of organizations and employee motivation especially as it affects financial incentives as a motivator for workers. (Bergum and Lehr's, 2004; Jibowo, 2007; ).. It is on the basis of the above arguments that the study undertakes an Assessment of Extrinsic Motivational variables Influence on Entrepreneurial Performances through the Perspectives of some selected SMEs in Lagos, Nigeria. The following research questions were formulated to pilot this study:

- What is the relationship between salary increment and entrepreneurial performance?

- Des job security have influence on entrepreneurial performance

- How does workers' regular promotion influence their entrepreneurial performance?

\section{Research Hypotheses}

Ho1: Salary increment for workers does not have any significant relationship withentrepreneurial performance.

Ho2: Job security for workers does not have any significant effect on their entrepreneurial performance.

Ho3: Regular promotion for workers has no significant influence on entrepreneurial performance.

\section{Literature Review and Conceptual Underpinning}

\section{Theoretical Background}

The motivational theories included in this research are linked to extrinsic motivation to find out what their possible influence could be on entrepreneurial performances. The motivational theories that are relevant for this research are the Equity theory, Expectancy theory and Goal-setting theory. Robbins (2003) and Adams (1963; 1965, in Harder, 1991) explain that the equity theory is a theory that centres on perceived fairness of an individual. An employee reflects on how much effort he has expended and compares this to what he has got from it. After this individual evaluation of his input-output ratio, he will compare his ratio to the inputoutput ratios of others, especially the direct peers. If the employee considers his input-output ratio to be equal to ratios of other relevant employees, a state of equity exists. In this situation of equity, the person is seemingly content and will not act to imbalance the condition (Cosier and Dalton, 2003). Naturally, when an employee perceives unequal ratios between him and his counterparts, there will be a state of inequity. Equity theory shows that beliefs, perceptions, and attitudes influence motivation. Employees are motivated powerfully to correct situations when there is a perception of inequity present at work.
On the other hand, Expectancy theory refers to a set of decision theories of work motivation and performance (Vroom, 1964; in Ferris, 2007). Perception plays a central role in expectancy theory because it emphasizes cognitive ability to anticipate likely consequences of behaviour (Kinicki et al., 2003). According to the expectancy theory, individual will be motivated to perform by two expectancies (Ferris 2007; Isaac et al. , 2001). The first expectancy is the probability that the effort put forth will lead to the desired performance. The second expectancy (also referred to as instrumentality) is the probability that a particular performance will lead to certain preferred outcomes. When the probability of some effort will not be rewarded, the employee will not be highly motivated to perform a certain task. External rewards are viewed as inducing motivational states that fuels behaviours, as opposed to intrinsic motivators, where behaviours are derived from internal forces such as enjoyment of the work itself because it is challenging, interesting, etc. (Isaac et al. , 2001).

In Goal-setting theory, Locke, Shaw, Sarri and Latham (2008) defined a goal as what an individual attempts to accomplish; it is the object or aim of certain action. The basic assumption of goal-setting is that goals are immediate regulators of human action (Locke et al., 2008). Evidence from the goal-setting research indicates that specific goals leads to increased performance and that difficult goal, when individuals have accepted them, result in higher performance than easy goals (Locke 1968 in Austin and Bobko, 1985; in Locke, 2004).

\section{Concept of Motivation}

Every organisation focuses on what should be done to attain high level of performance through its workforce. This mean giving close attention to how individuals can best be motivated through means such as reward, incentives and so on (Armstrong,2006) . Seth (2003) indicated that, motivation is an internal process that makes a person move toward a goal. He added that, motivation, like intelligence, can't be directly observed.

Buchanan (2010) opined that, motivation is a decisionmaking process, through which the individual chooses the desired outcomes and sets in motion the behaviour appropriate to them. Buchanan (2010) also defined motives as learned influences on human behaviour that lead us to pursue particular goals because they are valued. Motivation can therefore be thought of as the degree to which an individual wants and chooses to engage in certain behaviours.

\section{Types of Motivation}

Booth (2004) indicated that, motivation is the force that compels us to action. It drives us to work hard and pushes us to succeed. Booth (2004) added that, motivation influences our behaviour and our ability to accomplish goals. Curvin (2004) opined that, motivation is directly proportional to productivity. He added that, unless employees are highly disciplined they won't be productive if they were not motivated. Curvin (2004) continued that, there are many different forms of motivation and each one influences behaviour in its own unique way. He explained further that, no single type of motivation works for everyone and that, 


\section{International Journal of Science and Research (IJSR) \\ ISSN (Online): 2319-7064}

Index Copernicus Value (2015): 78.96 | Impact Factor (2015): 6.391

people's personalities vary and so accordingly does the type of motivation, that is most effective at inspiring their conduct. Motivation can divide into Internal/ Intrinsic and External/ Extrinsic.

Intrinsic motivation is done for reasons that are internal to one's self. It is for self-satisfaction and not for the fear of a consequence. The reward is within the action itself and does not need external factors to steer behaviour. Extrinsic motivation comes from external factors and the actions are done because of what has been said. This means that if we are told to do something, we do it because of extrinsic motivation. Introjected motivation also comes from within one's self, but if the action is not done, then the person is filled with guilt. The main difference between introjected and intrinsic motivation is the feeling of guilt. As extrinsic motivation rises, intrinsic motivation decreases because the person starts to only look for external rewards instead of working on something for personal satisfaction. There should always be a combination of both, but in essence, the person must be able to motivate from within to truly gain worth or a feeling of self-accomplishment from a task or goal.

\section{Entrepreneurial Skills and Entrepreneur Development}

It should be noted that entrepreneurs are not a well-defined occupational class of persons. Even obvious entrepreneurs may exhibit their entrepreneurship only during a certain phase of their career and or concerning a certain part of their activities/Entrepreneurial skills compares favourably with the basic skills required for starting, developing, financing and marketing business enterprises opined. Furthering this, entrepreneur is to start and successfully manage a business in a competitive environment. Studies have been conducted on the implication of entrepreneurial skills to business performance. However most of the studies were outside Nigeria which has its own peculiarities. The relationship between entrepreneurship skill and Entrepreneurial performance, using person product moment correlation and Regression Analysis, shows that out of the four entrepreneurial skills like business management, financial management, marketing and record keeping skills, the business management skill contributed more than others and that the financial management skill alongside increased the contribution. There are three fundamental propositions about entrepreneur skills thus; entrepreneur are successful to the extent that they have the necessary skills, entrepreneurs come to entrepreneurship at different level of skills and that entrepreneurial skills can be developed.

\section{SMEs Growth in Developed and Developing Countries}

SMEs have played a key role in the economies of both developed and developing countries in terms of turnover, level of employment and serve as a mechanism to fight against poverty as evidenced in the literature (Akanji, 2006; Akintoye and Oladejo, 2008; Akande, 2013). SMEs have been long recognized as an instrument ofeconomic growth and development. The importance of small and medium scale enterprises has not been in doubt; unfortunately classifying businesses into large and medium scale is subjective and premised on different value judgment. According to extant literature, the definition vary in different economics but the underlying concept is the same. Ojo
(2004); contends that the "definition of small and medium scale enterprises varies according to context, author and countries".

Small and medium scale enterprises are certainly not transnational company, multinational cooperation, publicly owned enterprises or large facility of any kind. However they can depend on business and ownership structure to become a large business unit (Liedholm C and Mead D (1987),) while it can be argued that $80 \%$ of the financing of SMEs come from owners, friends and families, business form can take different form including private ownership, limited partnership, contract and subcontracts, cooperatives or association ( Akande, 2005; Kozak, 2007). Small and medium scale enterprises have a narrow context within which its operation is carried out. However, where it is effectively operated it has capacity to sprout the economic growth and national development. Studies have confirmed that in every economics small and medium scale enterprises has been seen has a pivotal instrument of economic growth and development either in developed for developing economics. (.Ovia, 2000; Ojo, 2004, Asaolu 2004; Akande, 2005; Kozak, 2007; Oladejo, 2008). This claim is also supported by Adejumo and Olaoye (2012) who explain that the roles of SMEs in the national industrialization are eminent; they state further that SMEs contribute significantly to the Gross Domestic Product (GDP). Various government arms in Nigeria have made efforts to develop several policies and programs towards improving Small and Medium Enterprises (SMEs) activities in the country.

\section{Entrepreneurial Performance}

Ogundana (2012) stated that the concept of performance is used to determine the success of a business entity whether small or big. In 1999, the organization for economic cooperation and development (OECD) issued a document emphasizing that corporations should be run, first and foremost, in the interest of shareholders. This view of OECD is justified by two hundred years of research in economy and finance. It becomes obvious that the financial nature of performance is preferred. The International Accounting Standard Board (IASB) conceptual framework specifies that frequently, profit is used as a measure of performance. Performance is usually measured in term of earnings, profitability and dividend. Entrepreneurial performance can be measured in term of Business size, employment Capacity, turnover, capital base and profitability. Usually the profit is calculated as the net of turnover and associated cost.

\section{The Advantages of Extrinsic Motivation}

Extrinsic motivation comes from external sources, motivating you with incentives to boost performance. Extrinsic motivation carries distinct advantages and different employees display different motivational characteristics. Knowing which employees are motivated more extrinsically can improve individual Entrepreneurial skills.Using extrinsic motivation in the workplace can allow for a greater degree of control over operational processes. Extrinsically motivated employees require closer supervision to keep their performance high, allowing managers to closely watch and guide employees while they work. While close supervision may be intolerable to some, other employees thrive in 


\section{International Journal of Science and Research (IJSR) \\ ISSN (Online): 2319-7064}

Index Copernicus Value (2015): 78.96 | Impact Factor (2015): 6.391

situations where they have constant guidance and encouragement from supervisors.

\section{Methodology}

The study made use of cross-sectional survey design. The study area was Lagos, Nigeria, Lagos was selected because is a commercial nerve centre with $2^{\text {nd }}$ largest population in Nigeria (population Census Report 2006). Also, majority of registered businesses that could be used for the study were located in this area. multi-stage probability sampling technique was used, in which Lagos state was stratified into three geo political zone (Lagos-East, Lagos-Central and Lagos-West) from which the sample of various Owner of small medium scale enterprises(Entrepreneur) was drawn through the simple random sampling procedure. a sample of (400) Four hundred SMEs Owner were selected from a list of 4,535 registered SMEs in Lagos state .(NBS, 2012). The return rate for completed questionnaire was 78 percent as we were able to get back 310 usable questionnaires out of 400 personally administered to respondents which were employed for final analysis in this study. Data collected from the questionnaire were analyzed, summarized, and interpreted accordingly with the aid of descriptive statistical technique using simple percentages. A non-parametric statistical test such asT-test Analytical tool was used to test the formulated hypotheses.

\section{Result and Discussion}

\section{Presentation of Result}

Table1: Distribution of respondents according to business sector

\begin{tabular}{|l|c|l|}
\hline Sector & Frequency & $\%$ \\
\hline Manufacturing & 108 & 35 \\
Agro-Allied & 75 & 24 \\
Services & 127 & 41 \\
\hline Total & 310 & 100 \\
\hline
\end{tabular}

Source: Field study, 2017

Table 1 above shows that the highest percentage was $41 \%$ representing businesses that are service oriented, followed by manufacturing with $35 \%$ response rate, while those in agro-allied was $24 \%$.

\section{Perception of Entrepreneurs on the Influence of Salary Increment on entrepreneurial performances}

Table 2: Salary increase for workers can contribute positively to their entrepreneurial performances.

\begin{tabular}{|c|c|c|c|c|}
\hline Responses & Freq & Percent & $\begin{array}{c}\text { Valid } \\
\text { Percent }\end{array}$ & $\begin{array}{c}\text { Cum. } \\
\text { Percent }\end{array}$ \\
\hline Strongly Agree & 79 & 25 & 25 & 25 \\
\hline Agree & 151 & 49 & 49 & 74 \\
\hline Disagree & 68 & 22 & 22 & 96 \\
\hline Strongly Disagree & 12 & 4 & 4 & 100 \\
\hline Total & 310 & 100 & 100 & \\
\hline
\end{tabular}

Source: Field study, 2017

Table 2 above shows that $25 \%$ and $49 \%$ strongly agreed and agreed with the statement respectively that Salary increase for workers can contribute positively to their entrepreneurial performances, while only $4 \%$ strongly disagreed with it

Perception of Entrepreneurs on the Influence of Job Security on entrepreneurial performances

Table 3: Job security for workers can contribute positively to their entrepreneurial performances.

\begin{tabular}{|l|l|l|l|l|}
\hline Responses & Freq & Percent & $\begin{array}{l}\text { Valid } \\
\text { Percent }\end{array}$ & $\begin{array}{l}\text { Cum. } \\
\text { Percent }\end{array}$ \\
\hline Strongly Agree & 14 & 4 & 4 & 4 \\
\hline Agree & 65 & 21 & 21 & 25 \\
\hline Disagree & 89 & 29 & 29 & 54 \\
\hline Strongly Disagree & 142 & 46 & 46 & 100 \\
\hline Total & 310 & 100 & 100 & \\
\hline
\end{tabular}

Source: Field study, 2017

Table 3 above shows that $21 \%$ and $4 \%$ agreed and strongly agreed with the statement respectively that Job security for workers can contribute positively to their entrepreneurial performances, while $29 \%$ and $46 \%$ disagreed and strongly disagreed with the statement respectively.

Perception of Entrepreneurs on the Influence of Regular Promotion on entrepreneurial performances

Table 4: Regular promotion for workers can contribute positively to their entrepreneurial performances.

\begin{tabular}{|c|c|c|c|c|}
\hline Responses & Freq & Percent & $\begin{array}{c}\text { Valid } \\
\text { Percent }\end{array}$ & $\begin{array}{c}\text { Cum. } \\
\text { Percent }\end{array}$ \\
\hline Strongly Agree & 16 & 5 & 5 & 5 \\
\hline Agree & 43 & 14 & 14 & 19 \\
\hline Disagree & 113 & 36 & 36 & 55 \\
\hline Strongly Disagree & 138 & 45 & 45 & 100 \\
\hline Total & 310 & 100 & 100 & \\
\hline
\end{tabular}

Source: Field study, 2017

Table 4 above shows that $4 \%$ and $21 \%$ strongly agreed and agreed with the statement respectively that Job security for workers can contribute positively to their entrepreneurial performance, ,while $29 \%$ and $46 \%$ disagreed and strongly disagreed respectively with the statement.

\section{Test of Hypotheses}

This section deals with statistical testing of the hypotheses formulated to pilot this study and also interpreting the result making use of the T-test analysis statistical technique

Table 5: T-test of Hypothesis 1

$\mathbf{H o}^{1}$ : Salary increment for workers does not have any significant relationship with entrepreneurial performances.

\begin{tabular}{|l|l|l|l|l|l|}
\hline Variables & Frequency & $\mathrm{X}$ & $\mathrm{FX}$ & $\mathrm{X}-\overline{\mathrm{X}}$ & $(\mathrm{X}-\overline{\mathrm{X}})^{2}$ \\
\hline Strongly agree & 79 & 4 & 316 & -73.5 & 5402.25 \\
\hline Agree & 151 & 3 & 453 & -74.5 & 5550.25 \\
\hline Disagree & 68 & 2 & 136 & -75.5 & 5700.25 \\
\hline Strongly disagree & 12 & 1 & 12 & -76.5 & 5852.25 \\
\hline Total & 310 & 10 & 9170 & & 22505 \\
\hline
\end{tabular}

Source: Field study, 2017

Mean $(\ddot{\mathbf{X}})=310 / 4=77.5$

$\mathrm{T}$ - test calculated $=(\mathbf{X}-\ddot{\mathbf{X}})^{2} / \mathrm{fX}=22505$

Volume 6 Issue 7, July 2017 www.ijsr.net 


\section{International Journal of Science and Research (IJSR) \\ ISSN (Online): 2319-7064 \\ Index Copernicus Value (2015): 78.96 | Impact Factor (2015): 6.391}

From Table 5 above, the T-test analysis of the hypothesis shows that, using 95\% significance level, the result of $\mathrm{T}$ calculated was 2.5 and the T-tabulated at 6 degrees of freedom is 3.447. Since the T-calculated is lesser than the Ttabulated, we accept the null hypothesis that says Salary increase for workers does not have any significant relationship with entrepreneurial performances.

Table 6: T-test of Hypothesis 2

$\mathbf{H o}^{2}$ : Job security for workers does not have any significant effect on entrepreneurial performances.

\begin{tabular}{|l|l|l|l|l|l|}
\hline Variables & Frequency & $\mathrm{X}$ & $\mathrm{FX}$ & $\mathrm{X}-\overline{\mathrm{X}}$ & $(\mathrm{X}-\overline{\mathrm{X}})^{2}$ \\
\hline Strongly agree & 14 & 4 & 56 & -73.5 & 5402.25 \\
\hline Agree & 65 & 3 & 195 & -74.5 & 5550.25 \\
\hline Disagree & 89 & 2 & 178 & -75.5 & 5700.25 \\
\hline Strongly disagree & 428 & 1 & 142 & -76.5 & 5852.25 \\
\hline Total & 310 & 10 & 5710 & & 22505 \\
\hline
\end{tabular}

Source: Field study, 2017

Mean $(\ddot{X})=310 / 4=77.5$

$\mathrm{T}$ - test calculated $=(\mathrm{X}-\ddot{\mathrm{X}})^{2} / \mathrm{fx}=22505$

$=3.9$

\section{0}

From Table 6 above, the T-test analysis of the hypothesis shows that, using $95 \%$ significance level, the result of Tcalculated was 3.9 and the T-tabulated at 6 degrees of freedom is 3.447. Since the T-calculated is greater than the $\mathrm{T}$ - tabulated, we reject the null hypothesis that says job security for workers does not have any significant effect on entrepreneurial performances. We therefore accept the alternative hypothesis.

Table 7: T-test of Hypothesis 3

$\mathrm{Ho}^{2}$ : Regular promotion for workers has no significant influence on their entrepreneurial performances.

\begin{tabular}{|l|l|l|l|l|l|}
\hline Variables & Frequency & $\mathrm{X}$ & $\mathrm{FX}$ & $\mathrm{X}-\overline{\mathrm{X}}$ & $(\mathrm{X}-\overline{\mathrm{X}})^{2}$ \\
\hline Strongly agree & 16 & 4 & 64 & -73.5 & 5402.25 \\
\hline Agree & 43 & 3 & 129 & -74.5 & 5550.25 \\
\hline Disagree & 113 & 2 & 226 & -75.5 & 5700.25 \\
\hline Strongly disagree & 138 & 1 & 138 & -76.5 & 5852.25 \\
\hline Total & 310 & 10 & 5570 & & 22505 \\
\hline
\end{tabular}

Source:Field study, 2017

Mean $(\ddot{X})=310 / 4=77.5$

$\mathrm{T}$ - test calculated $=(\mathrm{X}-\ddot{\mathrm{X}})^{2} / \mathrm{fx}=22505$

$$
5570=4.04
$$

From Table 7 above, the T-test analysis of the hypothesis shows that, using $95 \%$ significance level, the result of $\mathrm{T}$ calculated was 4.04 and the T-tabulated at 6 degrees of freedom is 3.447 . Since the T-calculated is greater than the $\mathrm{T}$ - tabulated, we reject the null hypothesis that says regular promotion for workers has no significant influence on entrepreneurial performances. We therefore accept the alternative hypothesis.

\section{Discussion of Findings}

The first hypothesis which states that, salary increment for workers does not have any significant relationship with entrepreneurial performance was accepted. This shows that salary increase only is not enough a motivator for workers for a better performance. There must be other things attached to it. This is in line with equity theory which emphasizes that fairness in the remuneration package apart from the financial incentive tends to produce higher performance from workers. The findings also agrees with the work of Berjum et al (2004) which showed that subjects who received individual incentives based on choices performed better than those who do not receive, and workers exhibit productive work behaviour when rewards were made contingent upon performance.

The second and third hypotheses which state that job security for workers does not have any significant effect on their entrepreneurial performance and regular promotion for workers has no significant influence on their entrepreneurial performance respectively were rejected. This indicates that job security for workers, coupled with their regular promotion in their work places are very strong factors that propel the workers to put in their very best to the growth of the organisations they work for.Based on the foregoing, it can be said that it is pertinent for employers of labour to incorporate a worker-friendly policy apart from salary increase into their organisational policy statement so as to induce their employees to perform well on the job. In other word, the relevance of motivational factors depends not only on its ability to meet the needs of the employees, but also that of the organization as well.

\section{Conclusion and Recommendations}

Based on results obtained from the hypotheses, it can be concluded that the effect of extrinsic motivation on entrepreneurial performance is of paramount importance to the success story of any organization, and in order to meet up with the current dynamic rate of the business trends, Entrepreneurs should try as much as possible to adopt good and positive motivational techniques to increase the morale of the workers towards better performances. In line with this, it is recommended that Entrepreneurs should try as much as possible to adopt good and positive motivational techniques to increase the morale of the employee towards business performance.

\section{References}

[1] Abbasi Alireza (2007): E-Commerce development in Iran Webology, volume 4 number 4 December2007. http:/www.webology.ir/2007/4n4/a49.htm

[2] Adams, J. S. (1999). - Inequity in social exchange.l Advances in Experimental Social Psychology. New York: Academics Press. Pg 264-300.

[3] Akande, O.O (2013); "Does Entrepreneurship Programs Influence business performance? An Empirical Investigation of the Nigeria SMEs. International journal of Research in Commerce and Management.

Volume No.4, Issue No.09 (September 2013)

[4] Akande, O.O (2005): Effective Financing of Small/Medium Scale Enterprises (SMEs) as an Impetus for Poverty Alleviation in Nigeria: An Analytical Approach. International Journal of Economic and Development Issues. Development Universal Consortia. 5(1and 2), 1-13.

\section{Volume 6 Issue 7, July 2017 www.ijsr.net}




\section{International Journal of Science and Research (IJSR) \\ ISSN (Online): 2319-7064}

Index Copernicus Value (2015): 78.96 | Impact Factor (2015): 6.391

[5] Akanji O,O (2006): Microfinance as strategy for poverty reduction, CBN Economic and Financial Review, Vol.39 No 4.

[6] Akintoye I.R. and Oladejo M.O (2008): "Theory of Micro Enterprises. The Nigeria experience",International Journal of Social Sciences, University of Uyo, Akwa Ibom state Nigeria, Vol.3 No 7.

[7] Akerele, A. (2001). - Role of labour in productivity. Nigeria Journal of Industrial Relation, 5: 50-58. Assam, A.P. (2002).

[8] AlGhamdi, R, J. Nguyen, A. Nguyen \& S. Drew (2012), Factors Influencing e-commerce adoption by retailers in Saudi Arabia: a Quantitative Analysis, International Journal of Electronic Commerce Studies Vol.3, No.1, pp.83-100, 2012.

[9] Amabor, A., Akagbosu, S. And Amabor, Louis (2008): Extrinsic motivation and organisational productivity: A study of Bendel Feed and Flourmill Ltd, Ewu, Edo state, Nigeria. Research journal of Applied Sciences vol.3 Pp. 246-249

[10] Asaolu, T. O.(2004): Evaluation of the performance of the Cooperative Investment and Credit Societies(CICS) in financing Small-Scale Enterprises (SSEs) in Osun State, Nigeria.

[11] Bateman, T. and Snell, S., (1991). Management: Building competitive advantages, 4th edition, McGraw Hill Books international, Boston,

[12] Bansal S.C \& L Sharma (2006); Accounting for ecommerce in an emerging economy: a case study of India; Indian Institute of Management, Lucknow, India; bansal@iiml.ac.in

[13] Birchall, Johnston and hammond Ketilson, Lou (2009) 'resilience of the cooperative Business model in times of crisis', geneva: sustainable enterprise Programme, international Labour organization.

[14] Brynjolfsson, E \& Hitt, L.M. (1996) Paradox Lost? Firm-level evidence on the returns to information systems spending. Management Science, 42(4) 541558.

[15] Brynjolfsson, E \& Hitt, L.M. (2000) Beyond computation: information technology, organizational transformation and business performance. Journal of Economic Perspectives, 14(4): 24-48.

[16] Cosh, A.D. and Hughes, A. 2000. Innovation activity and performance in SMEs in Cosh, A.D. and Hughes, A. (eds.) British Enterprise in Transition: Growth Innovation and Public Policy in the small and medium sized enterprise sector 1994-1999

[17] Chukwuma, E. And Obiefuna, O. (2014): Effect of motivation on employee productivity. A study of manufacturing companies in Nnewi. International journal of managerial studies and Research. Vol.2 Pp. 137-147

[18] Clark, F. (2010). Fundamental of management: essential concept \&Application (5th edition). London: Raid International.

[19] Curvin, Y. (2004). Goal setting and job enrichment: an integrated approach to job design. The Academy of International Management Review.

[20] Evans, M.G. (2006). Organisational behavior: The central role of motivation. Journal of Management 12 (2), 203
[21] Eze, N. (2009). -Sources of Motivation among Nigerian Managers\| Journal of Social Psychology. 125: 341-345.

[22] Greeno, S. (2002). Human capital management: achieving added value through people. Kogan: Pager limited.

[23] Jesop, T. (2005). Improving employees performance through human resource management. London: Hoffman press.

[24] Jibowo, A.A. (2007). -Effect of motivators and hygiene factors on job performance among extension workers in the former Western State of Nigeriall. The Quarterly Journal of Administration, 12 (1):45-54.

[25] JImam, Hamra (2001). Potential of micro-credit , as poverty removal strategy, in research and policy direction on poverty in Nigeria: Centre for gender and social policy studies OAU IIe-Ife.

[26] JJames Manyika and Charles Roxburg, (2011). The great transformer: the impact of internet on economic growth and prosperity. An Appraisal of the Impact of Information Technology (IT) on Nigeria Small and Medium Enterprises (SMEs) Performance Akande Olusola And Yinus Oluwaseun Copyright (C) 2013 Helvetic Editions LTD - All Rights Reserved www.elvedit.com 151

[27] Kropp, Fredric \& Zolin, Roxanne (2008) Technological entrepreneurship and small business innovation programs. In Ghosh, Amithaba (Ed.) Impact of Government Policies on Marketing Strategies. ICFAI Press, Hyderabad, India, pp. 10-34.

[28] Kozak, S.J and Kowalski K.X (2005): "Effect of Technology on Consolidation level and Efficiency of Banking System", proceedings of the International Conference on ICTManagement, May 23-25 2005, Meleka Malaysia.

[29] Kagama, V.S (2014): Entrepreneurial performance and small business enterprises in Uganda. International journal of small business and entrepreneurial Research. Vol.2 Pp.1-12

[30] Kelly burton (2012): A study of motivation: How to get your employees moving. SPEA Honours Thesis Spring Indiana University.

[31] Lucchetti \& Sterlacchin (2004) "IT Adoption in small and medium-sized enterprises: elements for policy definition. Information Technology for Development, 7(4): 169-182

[32] Lai, J-Y and C. Yang, 2009. "Effects of Employees' Perceived Dependability on Success of Enterprise Applications in e-Business", Industrial Marketing Management, 38(3), pp.263- 274.

[33] Liedholm C and Mead D (1987), 'Small Scale Industries in Developing Countries: Empirical Evidenceand Policy Implications', International Development Pap er No.9, Dept of Agricultural Economics, Michigan State University, East Lansing, MI, USA.

[34] Mahmood, M. Adam and Mann Gary. J (2000); Special Issue: Impact of InformationTechnology on Organizational Performance vol 16, no4 pp3-10.

[35] Muhammad (2008): Grameen Bank, Microcredit and Millennium Development Goals; www.grameen.com www.grameen-info.org. 


\section{International Journal of Science and Research (IJSR) \\ ISSN (Online): 2319-7064}

Index Copernicus Value (2015): 78.96 | Impact Factor (2015): 6.391

[36] Muogbo, Uju (2013): The influence of motivation on employees' performance. A study of some selected firms in Anambra state. An international journal of Arts and Humanities. Vol.2 Pp. 134-151.

[37] Masud, I. (2015): Impact of motivation on employees' performance. A case of some selected Micro finance companies in Ghana. International journal of Economics, Commerce and Management. Vol. $111 \mathrm{Pp}$. 1218-1236.

[38] Nwachukwu, C.C (2004).Effective leadership and productivity. Evidence from a national survey of industrial organization.\| African Journal for the study of Social Issues, 1: 38-46.

[39] Narayan, Paresh , 2009. "Understanding the inflationoutput nexus for China," China Economic Review, Elsevier, vol. 20(1), pages 82-90, March.

[40] Odior, E. and Banuso, F. (2012). Cashless Banking in Nigeria: Challenges, Benefits and Policy. Implications. European Scientific Journal, 8(12), 289-316.

[41] Ojo, ,L (2004), Business ventures and the Nigerian economy, journal of economics, August 2004.

[42] Oladejo and Yinus (2013); An influential analysis of the Impact of Information Technology (IT) on Cooperative Services in Nigeria: (Accepted on 30th May 2013, with Manuscript ID: EJIBR-123, by European Journal of Business and Innovation Research; www.ea- journal.org.

[43] Oladejo M.O (2013); "Evaluation of the Nigerian microfinance Banks Credit Admnistration on Small and Medium Scale Enterprises Operations.

[44] Oladejo, M. O and Adereti, A. S (2010): The impact of Information Technology on the Performance of Micro finance Institutions in Nigeria, Journal of Economic Development and Managerial Studies, Vol.1 No.1, April 2010 edition. www.icidr.org

[45] Oladejo M.O (2008): Micro businesses and entrepreneurial development: an Explanatory accounting procedure. Proceeding of the first international conference on social economic policies and MDGs

Africa. Faculty of social and management sciences, Adekunle Ajasin university, Akungba Akoko, Ondo.

[46] Olivier, Henry (2000): "Challenges facing the accountancy profession", European Accounting Review,Volume 9, Issue 4 December 2000, pages 603 - 624. International Journal of Academic Research in Management Volume 2, Issue 4, 2013, ISSN: 22961747 Copyright (C) 2013 Helvetic Editions LTD - All Rights Reserved www.elvedit.com 152

[47] Ovia, Jim (2000); "Payment System and Financial Innovations. A paper presented at the Annual Policy Conference, Nov. 2002. Performance of Micro finance Institutions in Nigeria, Journal of Economic Development and Managerial Studies, Vol.1 No.1, April 2010 edition. www.icidr.org

[48] Popoola, S.O (2010), Management Perceptions of Internet - based Banking Services in Nigerian Commercial Banks; African Research \& Documentation; http://www.faqs.org.

[49] Robinson M.S (1999), The Microfinance Revolution: Sustainable Finance For The Poor: Lesson from Indonesia New York; Open Society Institute.
[50] Shiels, Rao, SS. and Mong C.A (2003): Electronic Commerce Development in Small and Medium sized enterprises. Business Project Management Journal, 9 (1) 11-32.

[51] Pannell, S. (2005). Organisational performance management. Dallas: Downe Publication Ltd.

[52] Stoneman, P. \& Toivanen O. (1997). The diffusion of multiple technologies: an empirical study Economics of Innovation and New Technology, 5: 1-18.

[53] World Development Report (1999). The Growing Economic and Political of Cities, Provinces and Other Sub-National Entities. April 1999, www.worldbanking.org.

[54] Yang, S., \& Lehto, X. (2007).Adoption of mobile technologies for Chinese consumers. Journal of Electronic Commerce Research, 8(3), 196-206. AUTHORS 